\title{
PREREQUISITES FOR SUCCESSFUL REGULATION OF REGIONAL INVESTMENT PROCESSES
}

\author{
${ }^{1}$ Morhachov Illia, ${ }^{2}$ Ovcharenko Ievgen \\ ${ }^{1}$ Assoc. Prof. Volodymyr Dahl East Ukrainian National University, Severodonetsk, Ukraine, \\ Email address morgachov.ilya@gmail.com \\ ${ }^{2}$ Prof. Volodymyr Dahl East Ukrainian National University, Severodonetsk, Ukraine, E-mail: evvoukr@gmail.com
}

Received 1605 2020; Accepted 31082020

\begin{abstract}
The purpose of this work is to test and evaluate the theoretical and methodological approach of objective selection of effective investment objects (mainly shares) on the stock market without the presence of insider information in order to improve the regulation of regional investment processes. The article considers the methodological and theoretical approach to optimizing the investment portfolio of securities. The positive qualities and disadvantages of this methodology are clarified. The practical use of this approach is shown on the example of the US stock market. An algorithm for applying the appropriate methodology based on a step-by-step assessment of investment performance by sectors (industries) to individual companies, taking into account the growth rate of the stock index "s\&P-500", is proposed. The use of the presented theoretical and methodological approach is justified for regulating regional investment processes in order to increase the results of regional investment funds and other subjects of regional investment activity.

Keywords: Regulation of Regional Investment Processes, Stock Market, Stock Index, ETF-fond, regional investment Fund.
\end{abstract}

JEL codes: Q16, M10.

\section{Introduction}

Successful investment processes are a significant factor in the development of both the economic entities that implement these processes, as well as the regions in which the relevant entities operate. That is why it is important to achieve success in regulating such processes at the regional level. At the regional level, investment processes are implemented by business entities that carry out commercial activities, including households, as well as regional investment funds. Successful investment activities of such entities are achieved through certain theoretical and methodological approaches that need to be defined.

Most investment processes are carried out through the stock market. However, this market is not homogeneous - it is divided by countries and their homogeneous groups. Many problems in implementing regional investment processes are related to the organization of the stock market.

The purpose of this work is to test and evaluate the theoretical and methodological approach of objective selection of effective investment objects (mainly shares) on the stock market without the presence of insider information in order to improve the regulation of regional investment processes. Analysis of literature sources in the direction [1-10] allows you to identify the presence of deep developments on the topic. In most of these and other sources considerate the problem of classifying investment stock markets into investment and speculative. However, for the implementation of investment processes, the target is the investment stock market. These are the characteristics of the US stock market. Unfortunately, other countries do not have such characteristics in the long run. So for individual business entities in the regions, including regional investment funds, it is more appropriate to purchase securities on the US stock market than anywhere else in other countries.

Copyright (C) 2020. Published by Vytautas Magnus University. This is an open access article distributed under the terms of the Creative Commons Attribution Non-Commercial 4.0 (CC BY-NC 4.0) license, which permits unrestricted use, distribution, and reproduction in any medium provided the original author and source are credited. The material cannot be used for commercial purposes. 
The US stock market is not homogeneous: there is significant choice by asset classes and issuers. Therefore, the task is to determine the theoretical and methodological provisions for selecting the most optimal assets for acquisition with investment purposes.

Most economists use the stock index "S\&P-500"as a comparison criterion. Its calculation includes 500 shares of leading American companies. If the growth rate of the price (value) of the selected asset exceeds the growth rate of the stock index "S\&P-500", then the choice of an asset for investment activities is appropriate. The optimal portfolio of securities is determined by maximizing the excess by over the corresponding index.

The US stock market is characterized by the fact that the main effect of owning shares is not so much to receive dividends as to increase the value of the shares themselves. In this case, the following formula should be chosen as the methodological basis for determining the average annual growth in the price of securities (CAGR) :

$$
\text { CAGR }=\left(\left(\frac{\mathrm{V}_{\mathrm{N}}}{\mathrm{V}_{0}}\right)^{\frac{1}{\mathrm{~N}}}-1\right) \cdot 100 \%
$$

where $\mathrm{V}_{\mathrm{N}}$ - is the final cost of investment;

$\mathrm{V}_{0}-$ initial cost of investment.

$\mathrm{N}$ - number of years.

$$
\mathrm{N}=\mathrm{N}_{\mathrm{k}}-\mathrm{N}_{0}
$$

where $\mathrm{N}_{\mathrm{k}}$ - final year for evaluation;

$\mathrm{N}_{0}-$ the starting year for evaluation.

It is also necessary to take into account the average annual level of dividends (D).

According to this model, the optimality criterion is the maximization of CAGR $+\mathrm{D} \rightarrow \max$.

Managers of regional investment funds, as well as other business entities that invest in the US stock market, undoubtedly cannot possess insider information about the object of investment. However, they can use the above model to analyze the rate of growth in the value of an investment over the past 10 or more years. At the same time, the main assumption will be that if the value of the investment object has grown in a certain way over the past 10 years, the same trend will generally continue in the future.

\section{Results}

If the success criterion is an excess by over the growth rate of the s\&P-500 stock index, we will determine its average annual growth (CAGR) during 2010-2020 (the time period from 01.01.2010 to 01.01.2020). a Graphic image of this index during 2010-2020 is shown in figure 1 .

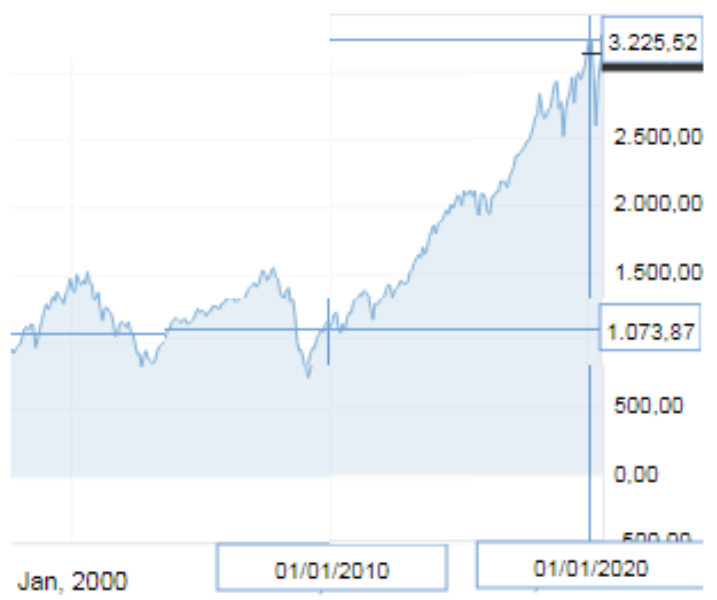

Fig. 1. Dynamics of the S\&P-500 stock index during 2010-2020 
According to Fig.1. the value of the CAGR is:

$\mathrm{CAGR}=\left(\left(\frac{3225,52}{1073,87}\right)^{\frac{1}{10}}-1\right) \bullet 100 \%=11,63 \%$

Unfortunately, the S\&P-500 index does not take into account the dividends paid by the respective companies included in this index.

The ETF "Vanguard S\&P 500" (VOO) - is an ETF that completely repeats the structure and, consequently, the dynamics of this Fund. The average amount of dividends of this Fund during the analyzed period was $1.5 \%$ per annum.

In this case the comparison criterion is the following value: $11,63 \%+1,5 \%=13,13 \%$. That is, the average growth rate of a potential investment object, including dividends, should exceed $13.13 \%$ per annum. Otherwise, it is advisable to buy shares of the ETF "Vanguard S\&P 500" (VOO).

ETF-Fund - a Fund traded on an exchange (English Exchange Traded Fund, ETF), exchange - traded investment Fund-an index Fund whose shares are traded on an exchange. The structure of the ETF follows the structure of the selected base index. Unlike an index mutual Fund, an ETF can be used for all operations that are available for ordinary shares in exchange trading. This is the main advantage of an ETF over a mutual Fund - operations on ETF shares can be performed throughout the trading day and their price changes depending on the activity of market participants. In fact, an ETF is a new type of securities that serves as a certificate for a portfolio of shares, bonds, and exchange-traded goods.

It should be added that in our case, the 10-year period: 2010 - 2020 (as of 01.01.2020) - fell on a period without crises. Therefore, the value of the growth rate of the stock index "s\&P-500" during the analyzed period is somewhat overestimated. In history, there was a crisis in 2008, as well as March 2020. However, in our research, we will focus on the methodology for selecting appropriate securities for investment.

The US stock market offers potential investors not only a large selection of stocks and bonds, but also a lot of ETFs, including by sector of the economy. If we are not specialists behind certain companies, we can buy shares of the corresponding ETF funds by sector. The average annual growth rate of such funds is estimated in table.1. The period 2010-2020 is chosen for the fact that many of the above ETFs have exactly this period of existence.

Table 1. Comparison of the level of efficiency of investments in ETFs

\begin{tabular}{|l|c|c|c|c|}
\hline \multicolumn{1}{|c|}{ Economic sector } & $\begin{array}{c}\text { Stock } \\
\text { Ticker }\end{array}$ & $\begin{array}{c}\text { Average annual } \\
\text { growth rate in 2010- } \\
\mathbf{2 0 2 0} \text { (CAGR), \% }\end{array}$ & $\begin{array}{c}\text { Average value of } \\
\text { dividend payments, \% } \\
\text { annual (D) }\end{array}$ & $\begin{array}{c}\text { CAGR + D } \\
\text { (\%) }\end{array}$ \\
\hline Utilities & VPU & 9,31 & 3,4 & 12,71 \\
\hline Finances & VFH & 9,97 & 2,91 & 12,87 \\
\hline Industry & VIS & 11,73 & 1,96 & 13,69 \\
\hline Health Care & VHT & 13,13 & 1,32 & 14,45 \\
\hline Information Technology & VGT & 17,57 & 1,08 & 18,65 \\
\hline Communication Services & VOX & 6,13 & 0,99 & 7,12 \\
\hline Materials & VAW & 7,25 & 2,11 & 9,36 \\
\hline Consumer Staples & VDC & 9,44 & 2,71 & 12,15 \\
\hline
\end{tabular}


The value of the CAGR in the table. 1 are high, that the study period is a period without crises and a period of growth after the 2008 crisis. If we take a more significant period, which includes the crisis, the value of the CAGR will be lower.

As noted earlier, there are many such funds, and we have selected several for testing the methodology. According to table.1. investments in only three sectors (industries) exceeded the efficiency mark more of $13.13 \%$. The most effective investments were in the "Information technology" sector.

The head of a regional investment Fund or other business entity can choose to invest in Vanguard Information Technology Index Fund ETF Shares or similar. However, if we are considering a methodological approach to maximize the effectiveness of investments in the stock market, we should apply the same methodology to securities (issuers) that are included in the sector (industry) that shows the highest results.

The Information technology sector includes such companies (table 2).

Table 2. Comparison of the level of investment efficiency in companies in the "Information technology"sector

\begin{tabular}{|l|c|c|c|c|}
\hline \multicolumn{1}{|c|}{ Name } & $\begin{array}{c}\text { Stock } \\
\text { Ticker }\end{array}$ & $\begin{array}{c}\text { Average annual } \\
\text { growth rate in 2010- } \\
\mathbf{2 0 2 0} \text { (CAGR), \% }\end{array}$ & $\begin{array}{c}\text { Average value of } \\
\text { dividend payments, } \\
\text { \% annual (D) }\end{array}$ & $\begin{array}{c}\text { CAGR + } \\
\text { D (\%) }\end{array}$ \\
\hline Microsoft Corporation & MSFT & 19,70 & 1,02 & 20,72 \\
\hline Oracle Corporation & ORCL & 8,56 & 1,74 & 10,30 \\
\hline Adobe Systems Incorporated & ADBE & 26,95 & - & 26,95 \\
\hline Salesforce.com Inc & CRM & 27,63 & - & 27,63 \\
\hline SAP AG ADR & SAP & 11,18 & 1,23 & 12,41 \\
\hline Apple Inc & AAPL & 27,42 & 0,91 & 28,33 \\
\hline Cisco Systems Inc & CSCO & 7,42 & 3,19 & 10,61 \\
\hline Citrix Systems Inc & CTXS & 5,86 & 0,97 & 6,83 \\
\hline Facebook Inc* & FB & 30,72 & - & 30,72 \\
\hline
\end{tabular}

*Note: Facebook Inc's stock data is for 7 years.

According to the presented methodology, investments in Facebook Inc, Apple Inc, and Adobe Systems Incorporated shares over the past 10 years have been more effective than the average.

In General, we used this algorithm:

1) Determining the time period for evaluation;

2) Calculation (CAGR + D) for the S\&P-500 stock index;

3) specification of the classification of companies by sector (industry);

4) Calculation (CAGR $+\mathrm{D})$ by sector (industry), determination of the latters the condition is fulfilled (CAGR $+\mathrm{D} \rightarrow \max )$;

5) Calculation (CAGR + D) by individual companies in the sector (industry) where (CAGR $+\mathrm{D} \rightarrow \max )$

6) Determining the list of companies with (CAGR $+\mathrm{D} \rightarrow \max )$;

7) Comparison $(\mathrm{CAGR}+\mathrm{D})$ of selected companies and and the rate of change in the stock index S\&P-500 stock index.

When considering the US stock market, it should also be clarified that it has a specific classification of companies by sector (industry), which may be unusual for other countries. In other words, a certain company in the United States may belong to a sector (industry) to which it would not be classified in the another country.

Problem in classification of companies by sector (industry) gives grounds for applying the presented methodology without analyzing the relevant sectors (industries), that is, without paragraphs 3 - 5. For the entire list of 500 companies included in the S\&P-500 stock index, you can 
determine the CAGR and evaluate the effectiveness of investments without taking into account the differentiation by sector (industry). In modern conditions, it is advisable to do this using Excel or GooglTabl software tools.

\section{Conclusion}

Considering objectively the positive sides and disadvantages of the above methodology, it should be noted that when forming an investment portfolio of securities, one should adhere to the principle of diversification. However, it is possible to create a diversified portfolio of companies from high-performing sectors (industries).

Considering the "Information technology" sector separately, it should be recognized that in modern conditions there is a risk of revaluation of shares in this sector, but it also has growth potential for the future.

As a certain disadvantage of the presented methodology, we can recognize a certain disregard for the effect of compound interest. This disadvantage can be neutralized by a more refined calculation of efficiency for the selected investment objects. Since this calculation is more complex, it is advisable to make it at the final stage, that is, after the preliminary selection of sectors( industries) and specific companies. In addition, this disadvantage for the US stock market is insignificant, since the main effect on it for investors is the growth in the value of assets, not dividend payments.

In General, this methodology allows managers of regional investment funds and other business entities to determine effective objects of investment in securities a relatively objective and short time in order to overcome the average growth rates of the entire stock market (the s\&P-500 stock index) without the presence of insider information.

The assessment methodology will become a factor in improving the regulation of regional investment processes if it acquires the status of a regulatory framework and instructions in the activities of investment entities that are subject to the control and(or) influence of public authorities.

\section{References}

Akinde, M. A., Peter E., Ikpefan O. A. Growth versus value investing: a case of Nigerian Stock Market // Investment Management and Financial Innovations, 2019. 16(1): 30-45.

Naik, P. K. Does stock market respond to economic fundamentals? Time series Analysis from Indian Data// Journal of Applied Economics and Business Research, 2013. 3(1): 34-50.

Jitendra, M., Ranjan, D. S. Asset Pricing Models - Cross Section of Expected Stock Returns and Financial Market Anomalies: A Review of Theories and Evidences // Journal of Management Research, 2016. 16(4): $230-249$.

Gurrib. I. The relationship between the Nasdaq Composite Index and energy futures markets // Investment Management and Financial Innovations, 2018. 15(4): 1-16.

116.

Koop, G., Korobilis, D. A New Index of Financial Conditions. European Economic Review, 2014. 71: 101-

Ivanenko, T., Hrushko, V., Frantsuz, A. Optimal investment decision making on the model of production enterprise with limited resources // Investment Management and Financial Innovations, 2018. 15(4): 61-68.

Chugunov, I., Pasichnyi, M. Fiscal stimuli and consolidation in emerging market economies. // Investment Management and Financial Innovations, 2018. 15(4): 113-122.

Burdorf, T., Vuuren, G. An evaluation and comparison of Value at Risk and Expected Shortfall // Investment Management and Financial Innovations, 2018. 15(4): 17-34.

Dyba, M., Gernego, I. Private Social Investments as a Solution for Rural Development // Management Theory and Studies for Rural Business and Infrastructure Development, 2018, Vol.40. No 3. pp. 320 - 328 . DOI: https://doi.org/10.15544/mts.2018.30

Morhachov I., Koreniev E., Chorna O., Khrystenko L. Regional Regulation of Investment Activity in Developing Countries: Example of Ukraine // Management Theory and Studies for Rural Business and Infrastructure Development. 2019. Vol. 41. No. 2: 168-182. 
